\title{
O TRÁFICO DE MULHERES E O SUBMUNDO JUDAICO NO ROMANCE MAASÊ BETABAAT [O RELATO DO ANEL], DE ILAN SHEINFELD
}

\section{THE TRAFFIC OF WOMEN AND THE JEWISH SUBWORLD IN THE ROMANCE MAASEH BETABAAT [A TALE OF A RING], BY ILAN SHEINFELD}

Gabriel Steinberg*

\section{Resumo}

No romance Maassê Betabaat, Ilan Sheinfeld traça a trajetória de duas famílias que, ao longo de três gerações, estão unidas pelos destinos de um anel com poderes mágicos e que se deslocam desde a cidade de Danzig até Buenos Aires, cidade para a qual milhares de judeus se dirigiram no final do século XIX, atrás de novas oportunidades econômicas. Entre eles, chegaram também aqueles que, determinados a prosperar através da exploração da prostituição, para lá levaram centenas de mulheres que foram transformadas em escravas sexuais. Nesse romance, Esperanza Gants revela à sua filha um nebuloso e terrível segredo: o de que ela, sua mãe e sua avó tinham sido prostitutas judias.

Palavras-chave: Literatura Judaica, América Latina, Argentina, Zwi Migdal.

\begin{abstract}
In the novel $A$ tale of a ring, Ilan Sheinfeld traces the trajectory of two families over three generations who are united by the destiny of a ring with magical powers, and they move from the city of Danzig to Buenos Aires, a city to which thousands of Jews immigrated in the late nineteenth century, in search of new economic opportunities. Among them, came also those who, determined to thrive by exploiting prostitution, sent hundreds of women who became sex slaves. In this novel, Esperanza Gants reveals to her daughter a dark and terrible secret: that she, her mother and her grandmother were Jewish prostitutes.
\end{abstract}

Keywords: Jewish Literature, Latin America, Argentina, Zwi Migdal.

\footnotetext{
* Professor de Língua Hebraica na Faculdade de Filosofia, Letras e Ciências Humanas da Universidade de São Paulo.
} 


\section{A organização Zwi Migdal em Buenos Aires}

No final do século XIX e, principalmente, a partir de 1880, as condições de vida dos judeus nos países do Leste da Europa levaram ao aumento do fluxo migratório em direção aos países da América. Entre a leva de judeus que chegou à região naquela época e até a década de 1940, estavam aqueles que, originários da Europa Oriental, dedicavam-se à exploração da prostituição e de atividades relacionadas a ela, no chamado "tráfico de escravas brancas". Brasil, Uruguai e, em especial, a Argentina, faziam parte de uma rede ampla de países onde as leis migratórias eram mais flexíveis, e as autoridades fingiam não ver o aumento da chegada de mulheres confinadas à força em bordeis. Os rufiões e as mulheres que por eles eram trazidas para a América, lugar no qual eram costumeiramente vendidas como simples mercadorias, não foram inclusos nas organizações comunitárias judaicas que estavam sendo criadas naqueles tempos.

Os judeus que tinham relação com a prostituição e com o tráfico de mulheres eram chamados "impuros" pelas organizações judaicas e, por isso, não tinham lugar dentro das comunidades, cujos membros se autodenominavam "puros", em oposição aos primeiros. Essa distinção se manifestou das mais diversas formas - em geral, na exclusão social. Segregados pelas comunidades judaicas que, em pleno processo de imigração massiva e na tentativa de se integrarem às sociedades dos países que as acolhiam, procuravam criar a respeito de si uma imagem positiva.

Em Buenos Aires, maior centro de prostituição até 1930, estabeleceu-se, em 1906, a organização Zwi Migdal. Desde a sua criação, essa entidade foi tida como uma organização criminosa, que aliciava e traficava mulheres, ludibriando-as desde sua partida da Europa até a chegada à América. A associação foi banida pela polícia e pela justiça argentinas em 1930 . Mesmo assim, seus integrantes tinham como propósito, além do tráfico de mulheres, a criação de uma sociedade de socorro e ajuda mútua, que contava com uma sede social, com sinagoga e até com um cemitério ${ }^{1}$, tentando ganhar, assim, um ar de respeitabilidade social. O número dos assim chamados "impuros" dentro da comunidade judaica argentina era relativamente pequeno. No início do século XX, a comunidade judaica da Argentina possuía por volta de 15

\footnotetext{
${ }^{1}$ O cemitério da Sociedad Israelita de Socorros Mútuos Varsóvia, que, posteriormente, mudou seu nome para Zwi Migdal, foi adquirido em 1906 no bairro de Avellaneda, na grande Buenos Aires. Atualmente, ele se encontra em estado de abandono, contendo mais de 2.000 túmulos de rufiões e prostitutas. Esse cemitério é contíguo ao Cemitério Israelita de Avellaneda, localizado na Av. Crisólogo Larralde, 14.100, no bairro de Villa Domínico.
} 
mil integrantes. Em 1930, seu número tinha passado para quase 200 mil. Em 1932, quando a organização criminosa tinha sido desbaratada, a polícia contava com 600 nomes de integrantes da Zwi Migdal (LORI, 2009, p. 1).

$\mathrm{Na}$ noite do réveillon, em 31 de dezembro de 1929, o inspetor da Polícia Federal argentina, Julio Alsogaray, encontrava-se em seu escritório, em Buenos Aires. Do outro lado da porta, aguardava-o uma mulher que viria a mudar a sua vida, assim como abalar profundamente a rotina da comunidade judaica da capital. Alsogaray, um caso raro de um policial incorruptível na época, tinha tentado, anos antes, desmontar as organizações criminosas, tanto judias como não judias, que traficavam e negociavam com mulheres na cidade. Ao abrir a porta, deparou-se com Raquel Lea Liberman, a prostituta judia que o ajudaria a desarticular a máfia judia. Liberman transformou-se, provavelmente, na primeira combatente do terrível tráfico internacional de mulheres no mundo. Seu depoimento ao policial se prolongou por vários dias. Em maio de 1930, quase seis meses após os depoimentos de Liberman, teve início o desmonte de uma das maiores organizações criminosas da América Latina, marca de vergonha para as comunidades judaicas da época.

Sob o falso manto de sociedades de ajuda mútua e de caridade, imigrantes judeus que chegaram do Leste da Europa a partir da década de 70 do século XIX, ergueram, em vários locais da América Latina, sobretudo em Buenos Aires, casas de prostituição, onde comercializavam, extorquiam e se aproveitavam de milhares de jovens judias, muitas das quais, consciente ou inconscientemente, embarcavam voluntariamente, sabendo, de antemão, que destino teriam. Outras, porém, eram trazidas à força, a fim de serem vendidas em "leilões públicos" a quem desse o melhor lance. Essas mulheres eram condenadas a passar o resto de suas vidas sob a marca da vergonha e do escárnio publico e a permanecer no ostracismo social e comunitário judaico. A organização que, em 1906, adotou, inicialmente, o nome Sociedad Israelita de Socorros Mútuos Varsóvia contava, desde sua constituição, com a conivência das autoridades políticas e policiais de Buenos Aires, que recebiam suborno e se utilizavam de seus serviços. Os líderes da organização mantiveram um padrão de vida e uma exposição de luxo e de ostentação durante sessenta anos ao menos, valendo-se da violência para neutralizar toda oposição a suas lucrativas atividades. Em 1927, por pressão do cônsul da Polônia em Buenos Aires, a organização foi obrigada a mudar de nome - o que mostra que sua má fama tinha ultrapassado as fronteiras argentinas. Zwi Migdal, a nova denominação, homenageava um dos antigos líderes desse grupo, Henrik Zwi Migdal. 
A vergonha e o constrangimento que a existência da Zwi Migdal provocou na comunidade judaica eram muito grandes, e a divisão entre "puros" e "impuros", cada vez mais nítida. Os integrantes dos dois grupos optaram, naqueles anos e ao longo das décadas seguintes, por apagar essas lembranças da memória coletiva judaica, tanto na Argentina como no Uruguai e também no Brasil. Por esse motivo, são poucos os dados que foram desvendados, e a divulgação mais ampla teve início há duas ou três décadas. Uma das fontes mais fidedignas é o livro escrito pelo inspetor Julio Alsogaray (1933), que desmontou a Zwi Migdal. Ele estimou em algumas centenas o número de mulheres judias ashkenazitas que, nessas décadas, se ocupavam da prostituição e cogitou que havia, aproximadamente, 200 casas oficiais e não oficiais que empregavam, em Buenos Aires, essas mulheres e atendiam clientes de todas as classes sociais da capital. Naquela época, a prostituição era uma atividade legal na Argentina, e cada mulher que exercia a profissão era obrigada a registrar-se no serviço de higiene da prefeitura, que exercia, assim, supostamente, um controle sobre a propagação de doenças sexualmente transmissíveis.

Quem ajudou a pôr fim à organização em Buenos Aires foi Raquel Liberman. Liberman nasceu em julho de 1900, em Berdichev, Polônia (hoje, parte da Ucrânia). Na infância, mudou-se com sua família para Varsóvia e, em 1919, casou-se com Yaacov Ferber, um humilde alfaiate em Lodz. Um ano depois, nasceu seu primogênito, Yeoshua David. Em 1921, quando estava grávida do segundo filho, seu esposo embarcou rumo a Buenos Aires, assim como milhares de outros judeus, à procura de novas oportunidades econômicas. Ali já morava a irmã de Yaacov Ferber, Elka, com seu marido, na pequena localidade de Tapalqué, no centro da província de Buenos Aires. Com base nas cartas que Yaacov enviou para sua esposa Raquel na Polônia, é impossível saber o que ele fazia em Buenos Aires, cidade que descreveu como "terra das oportunidades" (LORI, 2009, p. 3). Em outubro de 1922, Raquel Liberman desembarcou com seus dois filhos pequenos em Buenos Aires. Um ano depois, Yaacov morreu de tuberculose. Sem alternativas, Raquel deixou seus filhos em Tapalqué e embarcou rumo à grande cidade à procura de emprego como costureira. Sem conhecer a língua do país, acabou se envolvendo, em 1924, com Jaime Kissinger, o qual, com promessas de casamento, acabou introduzindo-a no escuro mundo da prostituição. Documentos encontrados posteriormente por Julio Alsogaray sugerem que Elka Ferber, a cunhada de Raquel, e seu marido faziam parte da Zwi Migdal. 
Kissinger a obrigou a trabalhar numa das casas da Zwi Migdal, onde ela permaneceu por cinco anos, tempo no qual sustentou seu cafetão e seus filhos, que tinham permanecido no interior de Buenos Aires. Ao cabo desse período, ela conseguiu, por 90 mil pesos, comprar sua liberdade. Livre da Zwi Migdal, Raquel acabou abrindo um comércio de artigos musicais e de arte no centro da cidade. Em julho de 1928, Raquel se dirigiu, pela primeira vez, ao inspetor de polícia Julio Alsogaray, declarou-lhe que ela tinha se desligado da prostituição e lhe solicitou que seu nome fosse retirado oficialmente do cadastro que a policia possuía. Nessa ocasião, relatou também ao policial seu receio de ser perseguida pelo cafetão e pelos longos braços da organização.

Essa foi a primeira vez em que Alsogaray se deparou com a brutalidade e a ramificação desse núcleo; porém, faltava-lhe um elemento fundamental para poder agir: uma denúncia formal. O temor de Liberman se confirmou quando, um dia, José Korn, figura conhecida do "submundo" e um dos "impuros", conseguiu iludir Raquel com uma promessa de casamento. Dessa forma, dez meses após comprar sua liberdade, Raquel Liberman se viu obrigada a retornar à prostituição e, agora, sob a égide de um novo cafetão, que fazia parte da mesma organização criminosa. Liberman não se intimidou e apresentou uma denúncia à Zwi Migdal, reclamando sua liberdade e denunciando Korn. Ela também não se silenciou mesmo quando um dos integrantes da organização, Maurício Kirstein, ameaçou matá-la. A seguir, na noite de réveillon de 1929, ela se apresentou diante de Julio Alsogaray, que, juntamente com o juiz federal Manuel Rodriguez Ocampo e com Zelig Gnopol, secretário da organização judaica Ezrat Nashim ${ }^{2}$, que já lutava contra a Zwi Migdal, conseguiram pôr um fim à organização e levar a julgamento, pelo menos, 108 chefes da agrupação criminosa.

Os advogados da Zwi Migdal agiram rapidamente, mas, na mesma época, a Argentina sofreu um golpe militar. A imprensa mobilizou a opinião pública contra o tráfico de mulheres, e o novo governo implementou uma lei de 1902, segundo a qual era possível expulsar do país estrangeiros que provocassem agitação social ou se envolvessem em atividades criminosas e

\footnotetext{
${ }^{2}$ A organização Ezrat Nashim surgiu em Buenos Aires em 1920, com o intuito de defender as mulheres judias do país - em especial, para atender às crescentes denúncias contra o tráfico de mulheres. A Ezrat Nashim atuou até o ano de 1966. Em seus arquivos, encontra-se uma grande quantidade de cartas remetidas pelo consulado da Polônia em Buenos Aires, com pedidos de busca enviados por mulheres que, juntamente com seus filhos, tinham sido abandonadas pelos maridos, os quais se encontravam, supostamente, na Argentina ou cujos paradeiros eram ignorados. Por causa da má reputação da organização Zwi Migdal, muitas famílias judias da Europa se dirigiram à Ezrat Nashim, solicitando informações sobre a idoneidade de potenciais noivos ou noivas na Argentina. A organização atuou também no auxílio às mulheres vítimas do tráfico e destinadas à prostituição. $60 \%$ das cartas do arquivo da Ezrat Nashim foram escritas em espanhol ou num misto de espanhol e ídiche, e 33\% delas, que consistem em pedidos diversos ou outros documentos, foram escritas apenas em ídiche (The Nacional Library of Israel).
} 
também anular a naturalização daqueles que a tinham conseguido anteriormente. Mesmo que alguns chefes dos chamados "impuros" tenham conseguido se livrar da prisão, já que seus contatos com as autoridades políticas e policiais eram conhecidos, após a prisão e o desmonte da organização, eles não conseguiram mais reconquistar o poder de antigamente. Alguns foram para a clandestinidade, outros foram expulsos do país, outros fugiram para o Uruguai e o Brasil, onde reiniciaram suas antigas atividades no mundo da prostituição. José Korn foi condenado a 10 anos de prisão e a indenizar monetariamente sua vítima. Raquel Liberman não conseguiu, no entanto, usufruir da almejada liberdade. Ela morreu de câncer em Buenos Aires, no ano de 1935, aos 35 anos de idade.

Raquel Liberman tornou-se uma figura emblemática para o povo argentino nas últimas décadas. É importante ressaltar que, anualmente, o governo da Cidade Autônoma de Buenos Aires, através da Subsecretaria de Direitos Humanos e Pluralismo Cultural, outorga o prêmio Raquel Liberman ${ }^{3}$ às vítimas de violência doméstica ou a indivíduos e organizações não governamentais que promovem atividades ou que lutam para proteger os direitos das mulheres em situação de risco. A essa iniciativa se soma a moção das deputadas argentinas Silvia Vázquez e Maria Luisa Storani, que, em 2011, propuseram à Câmara dos Deputados da Argentina o reconhecimento oficial de Raquel Liberman como "vítima e primeira lutadora contra o tráfico internacional de pessoas"4.

Outro aspecto importante no romance Em torno de um anel e que aparece também no romance $O$ ciclo das águas, de Moacyr Scliar - provavelmente, um dos primeiros romances em português a trazer à tona a temática das mulheres judias obrigadas a se dedicar à prostituição no Brasil -, era a vontade de manter as tradições judaicas que tinham os judeus de todas as correntes, mesmo os chamados "impuros", ao chegar a Buenos Aires e a outras cidades, como Rio de Janeiro, Santos, Manaus. Conforme diz Alberto Dines, na apresentação do livro de Beatriz Kushnir, Baile de máscaras, em referência às "polacas” no Rio de Janeiro, ou seja, às mulheres judias que para cá foram trazidas na mesma época - e isso se aplica certamente às mulheres obrigadas a serem prostitutas em outros lugares da América -, elas

eram chamadas em ídiche die linke, literalmente as esquerdistas, mas na realidade, eram as outras, as marginais, as que ficaram na contramão da rígida moral da comunidade [...]. Tiradas da miséria dos guetos e das pequenas cidades da Europa Oriental, foram enfiadas

\footnotetext{
${ }^{3}$ Disponível em: $<$ http//www.buenosaires.gob.ar/raquelliberman $>$ Acesso em: 11 mai. 2016.

${ }^{4}$ Disponível em: $<$ http//www.diarioelargentino.com.ar/noticias/99806/reconocimiento-a-raquel-libermanpionera-contra-la-trata-de-personas $>$ Acesso em: 11 mai. 2016.
} 
nos bordéis da Praça Once e da Lapa. As polacas logo converteram-se em cafetinas, muitas casaram-se com seus rufiões e constituíram família. O surpreendente é que, apesar da rigorosa segregação a que foram condenadas pelos conterrâneos e correligionários, não se assimilaram ao meio brasileiro no qual estavam integradas de forma tão aviltante. Ao contrário, mantiveram intacta a herança cultural que trouxeram na bagagem. Confinadas ao submundo, constituíram uma sub-comunidade organizada: tinham seu cemitério, sua sinagoga com os rolos sagrados [...], organizaram sua sociedade beneficente, até montavam seus próprios espetáculos teatrais.

\section{O romance Maassê Betabaat, de Ilan Sheinfeld}

No romance histórico Maassê Betabaat ( $O$ relato do anel), o escritor israelense Ilan Sheinfeld traça a trajetória de duas famílias que, ao longo de três gerações, permaneceram unidas pelos destinos de um anel com poderes mágicos de cura da epilepsia e que se deslocam desde a cidade de Danzig (ou Gdansk, na atual Polônia), onde a narrativa se inicia, até Buenos Aires, cidade para a qual milhares de judeus se dirigiram a partir do final do século XIX, atrás de novas oportunidades econômicas. Entre eles, chegaram aqueles que, determinados a prosperar através da exploração da prostituição, para lá levaram centenas de mulheres, as quais foram transformadas em escravas sexuais. Nesse romance, Esperanza Lea Gants revela à sua filha Flora um nebuloso e terrível segredo: o de que ela, sua mãe e sua avó tinham sido prostitutas judias. As três mulheres foram marcadas por um anel que, transmitido em herança de geração a geração, perpetuou a mácula da vergonha que essas carregaram desde Danzig até Buenos Aires.

Esperanza Lea Gants, no romance, é uma velha prostituta argentina que decide revelar à sua filha Flora, com quem mora em Israel, a verdadeira história de sua vida. Esperanza, que é a narradora do livro, conta sua própria trajetória e desvenda o passado de sua mãe, Esther, e de sua avó, Lea, uma dinastia de mulheres que se dedicaram à prostituição por diferentes motivos. Paralelamente, Esperanza conta a Flora sobre a aristocrática família Bergman, cujo percurso esteve emaranhado com a vida de Lea, de Esther e da própria Esperanza, por causa do misterioso e poderoso anel, capaz de curar ou abrandar os efeitos da epilepsia nas duas famílias. Esperanza somente ousa revelar a Flora seu mistério depois que as duas conseguiram fugir do regime militar que se instaurou na Argentina a partir de 1976, o qual perseguiu ferozmente tanto intelectuais como revolucionários de esquerda - muitos dos quais eram de origem judaica, como no caso de Flora -, assim como mulheres consideradas "degeneradas

\footnotetext{
${ }^{5}$ Palavras de Alberto Dines na apresentação do livro Baile das máscaras (KUSHNIR, 1996).
} 
sociais e morais", como no caso da velha prostituta Esperanza Gants. Somente em Israel, o lar dos judeus perseguidos por todas as razões existentes no mundo, é que Esperanza finalmente conseguirá descansar da dor, da vergonha e da tristeza que acompanharam a história de sua existência, bem como a de sua mãe e a de sua avó (HERMONI, 2007).

O romance de Ilan Sheinfeld se centra também no assentamento dos judeus nas colônias agrícolas criadas na Argentina pelo Barão Maurice de Hirsch, que, a partir da criação da organização JCA (Jewish Colonization Association), em 1891, buscou apresentar uma solução alternativa ao Sionismo proposto na mesma época por Theodor Herzl e salvar os judeus do Leste da Europa, submetidos aos constantes pogroms. Hirsch assentou milhares deles na América Latina e, em especial, nas colônias agrícolas que ele criara na Argentina. Do ponto de vista histórico, o romance se inicia em 1881, data do grande pogrom na Rússia e do início da primeira aliá, a primeira onda imigratória para a Palestina. Mas esse acontecimento não é mencionado no romance, que dá destaque à grande imigração judaica rumo à Argentina. Os judeus que chegavam da Europa Oriental à América Latina eram movidos pela esperança de um recomeço numa terra nova e pouco habitada; e é aqui na América que se desvenda, perante o leitor, uma história nebulosa, um relato carregado de vergonha e mantido por décadas num total silêncio.

Paralelamente às imigrações rumo à Palestina, para onde afluíam jovens que, saindo da Rússia, tinham o intuito de se tornar agricultores, alguns judeus, na Argentina, encontraram um modo de sustento baseado, sobretudo, na prostituição. As jovens - muitas vezes, suas vítimas - eram iludidas, em geral, com promessas de emprego ou de casamento e acabavam trocando uma miséria por outra. O romance sinaliza de forma irônica a tensão existente entre os "puros" e os "impuros" e apresenta o mundo judaico do início do século XX de forma antagônica, dividido entre bons e maus, oprimidos e opressores. As mulheres pagavam um alto preço ao imigrar para o novo mundo: elas eram entregues por seus pais a emissários ou aos próprios rufiões, como no caso de Esther, que foi entregue pela própria mãe, Lea, a Manuel, o elegante e charmoso comerciante que fez sucesso na Argentina e prometeu a Lea um bom emprego no novo país para sua jovem filha. Os pais confiavam suas filhas a tais homens, sem saberem que elas estavam destinadas a se transformar em prostitutas.

Algumas das moças chegavam de lares religiosos, como Miriam, a filha do rabino, que foi colocada no mesmo navio que Esther. Ali mesmo, no porão, foram as duas violentamente estupradas por três marinheiros a mando de Manuel, o cafetão, que, com lindas palavras, as 
arrancara de seus lares. Elas deviam entender, com esse episódio, quem mandava, a partir de então, em suas vidas e a quem deviam obediência absoluta, desde aquele momento e até o final de seus dias. A ironia no romance é que Lea, a prostituta de Danzig, tenta mudar o destino de sua filha, Esther, e envia-a para a Argentina, a fim de que ali ela tivesse uma nova oportunidade. Quem, porém, a acompanha para o novo mundo é justamente aquele que a transformará numa prostituta. Esther, assim como Lea, a prostituta de Danzig, seguirá o mesmo caminho que sua mãe, mas em Buenos Aires.

Na cidade argentina, Bela Bergman é quem descobre a grande ramificação do comércio de brancas, assim como o tamanho da organização criminosa. O tráfico de mulheres tivera início nos anos noventa do século XIX, quando ela era ainda uma mulher jovem. As primeiras moças foram tomadas de aldeias na Hungria e na Polônia. Suas famílias viviam na extrema pobreza, e as filhas, jovens sem dote algum, transformaram-se em mercadoria de troca em mãos de seus pais, em sua permanente luta pela sobrevivência. Os mercadores de mulheres encontravam, assim, um fértil campo de atuação nas difíceis condições econômicas enfrentadas pelos judeus naquela época, que também sofriam em decorrência da constante pressão antissemita que vigorava naquelas terras. Os traficantes, aproveitando-se do desespero generalizado, chegavam às aldeias comportando-se como homens ricos e respeitáveis e ofereciam aos pais a possibilidade de empregarem suas filhas em casas de famílias judias já estabelecidas em Buenos Aires. Ainda tinham por hábito pagar aos pais um adiantamento do futuro salário a ser recebido pelas jovens. Dessa forma, muitos pais entregavam suas filhas nas mãos desses traficantes de mulheres e, ainda, depositavam em suas mãos todos os seus documentos, contribuindo para o aprisionamento perpétuo das jovens.

Ao desembarcarem em Buenos Aires, esses comerciantes distribuíam as moças que traziam consigo entre as casas de prostituição da própria cidade, mas também em Rosário, Córdoba, Mendoza, Tucumán e até fora das fronteiras argentinas - em Montevidéu e em diversas cidades do Brasil. Havia rufiões que depositavam antecipadamente, em mãos dos comerciantes, o dinheiro das passagens, de modo que, quando as jovens chegavam, eram trancadas em casas de passagem por dois ou três dias e, depois, obrigadas a comparecer a leilões públicos perante outros cafetões judeus, donos dos bordéis ou intermediários de mulheres da cidade.

As jovens eram, então, imediatamente obrigadas a tornarem-se prostitutas, e toda tentativa de rebelião era passível de punição, que ia desde castigos físicos até o 
encarceramento em solitárias por períodos prolongados. E, se essas mulheres mostrassem interesse em serem redimidas, ou seja, se manifestassem o desejo de serem libertas da profissão, seus rufiões impunham-lhes valores bastante elevados, nos quais incluíam não apenas o valor da passagem, mas o valor que haviam pagado pelas próprias jovens nos leilões públicos, além dos gastos com roupas e alimentação e dos cálculos referentes aos lucros futuros que elas gerariam a seus empregadores. Esses cálculos tornavam impossíveis as tentativas das famílias ou de filantropos da comunidade judaica de redimir essas mulheres e lhes possibilitar o retorno a uma vida livre e digna (SHEINFELD, 2007, p. 284-285).

A narrativa do romance tem início no século XIX, na aldeia de Shedletz, com Naftali Braine e sua esposa, Bruria, pais de Raine Haia, que, ainda jovem, foi acometida pela epilepsia, doença que se manifestava com frequência e que, no romance, perdura por três gerações. Com fortes elementos do realismo mágico, o narrador conta que os pais foram aconselhados a procurar o Rabi Mendel de Kotchek, um conhecido rabino milagreiro, o qual seria capaz de encontrar uma solução para os ataques cada vez mais frequentes. A pedido dele, os pais de Raine Haia dirigiram-se à grande cidade de Danzig. Foi na sinagoga dessa cidade que o casal conheceu Zeharia Bergman, o ourives, que confeccionou um anel especial, em cujo interior foram gravados alguns versículos, conforme fora determinado pelo rabino Mendel de Kotchek. O anel uniu, sob o mesmo teto, os jovens Raine Haia e Shmuel Bergamn, filho do ourives. Eles tiveram quatro filhos, dos quais o primogênito era Guershon.

Um dia, o anel com poderes misteriosos de cura foi roubado da casa da família Bergman. O ladrão era um judeu da Romênia, um marceneiro chamado Leizer Kochman. Não foi o valor econômico que o atraiu, pois o anel se destinava à sua amada, Lea, que, como Raine Haia, sofria de epilepsia. Lea, órfã de pai e mãe, tinha nascido no seio de uma família humilde de Lodz. Sua mãe morrera ao seu nascimento, e seu pai se afogou num rio, deixandoa sozinha. Lea tornou-se prostituta, seu único modo de sustento. Leizer Kochman encantou-se por ela e decidiu transformá-la em sua esposa. O furto do anel da família Bergman tinha por objetivo aliviar o sofrimento de Lea, causado pelos constantes ataques da assustadora doença.

$\mathrm{Na}$ casa da família Bergman, Guershon casou-se com a rica Bela Litvinovsky. A mãe de Guershon, Raine Haia, os fez jurar, no leito de morte, que tanto ele como ela fariam todo o esforço possível para devolver o anel à sua família e para colocá-lo no dedo de Bela. A seguir, durante um ataque epilético, Raine Haia faleceu, deixando Bela Bergman obcecada por aquele anel, e essa obsessão a persegue por todo o romance. No mesmo dia em que Raine Haia 
morreu, Lea Kochman deu à luz a uma filha, cujo pai tinha sido um antigo cliente. Leizer Kochman exige que a bastarda seja entregue por Lea a um orfanato em Danzig. Lea, contudo, não se separou de sua filha, a qual visitava periodicamente no orfanato, fazendo-a saber que ela era sua mãe. Enquanto isso, na casa dos Bergamn, Bela ficava cada vez mais obcecada pelo anel, mas seu esposo, Guershon, estava ocupado com outros assuntos, como diz o narrador: "Ele dedicava-se a ler O Estado Judeu de Theodor Herzl e acompanhava os preparativos para a organização do $1^{\circ}$ Congresso Sionista em Basiléia" (SHEINFELD, 2007, p.85).

Um dia, Leizer Kochman, o marceneiro responsável pelo furto do anel, foi esmagado por uma das máquinas de sua marcenaria e morreu. Assim que Leizer foi sepultado, Lea Kochman foi até o orfanato, de onde retirou a filha Esther, que tinha 10 anos de idade, e também o anel, o qual deixara lá depositado como garantia da permanência na instituição. Lea abriu uma taverna na oficina deixada por Leizer, onde servia refeições para os marinheiros cujos navios atracavam no porto de Danzig, local próximo à sua taverna. Entrementes, Bela Bergman ficou sabendo, consultando clínicas médicas da cidade, que, naquele lugar, havia outra mulher que aliviava as sequelas da epilepsia com o uso de um anel misterioso. Essa mulher era Lea Kochman, uma antiga prostituta, cujo esposo, Leizer, lhe trouxera o mencionado anel depois de furtá-lo da casa da família Bergman.

Temerosa pelo futuro de Esther, sua filha, que se transformara numa bela jovem, e sabendo que alguém estava à sua procura por causa do misterioso anel dado a ela de presente por seu falecido esposo, Lea, um dia, deparou-se com relatos a respeito de mulheres e homens ricos e honrados, que percorriam a cidade atrás de jovens judias, as quais, diziam as notícias que circulavam de boca a boca, eram enviadas a Buenos Aires, com a promessa de conseguirem bons casamentos, isto é, casamentos com membros de famílias judias igualmente honradas e já estabelecidas naquela cidade. Lea ouviu, pela primeira vez na vida, da boca daquelas elegantes pessoas, que a Argentina tinha aberto suas fronteiras e estava recebendo imigrantes de todo o mundo, inclusive judeus, e ouviu também a respeito do projeto de colonização da JCA, que era financiado pelo banqueiro judeu, o Barão Maurice de Hirsch (SHEINFELD, 2007, p. 99).

Querendo salvar sua filha da marca do opróbio que sobre ela mesma pairava em toda a cidade de Danzig, Lea chamou sua filha e lhe disse: 
Esther, a vida nesta cidade está a cada dia mais perigosa. Estou muito preocupada contigo. Você ouviu alguma vez falar sobre a Argentina? [...] Argentina é um país novo, grande e livre. É um país no qual os judeus não são perseguidos. Na Argentina moram alguns membros da minha antiga comunidade, e agora judeus estão se assentando ali nas colônias agrícolas para dar início a uma nova vida. (SHEINFELD, 2007, p. 100 - 101)

Mesmo com a resistência demonstrada por Esther - que, sendo muito jovem, não queria ir para um país desconhecido nem se separar de sua mãe, mesmo que sua mãe tivesse a má reputação de ter sido, até pouco tempo atrás, uma prostituta -, isto não demoveu Lea Kochman. Era preciso salvar Esther da possibilidade de sua filha vir a seguir, obrigada pela pobreza, os passos de sua mãe. A Argentina mostrava-se um lugar promissor para iniciar uma nova vida e uma nova existência. Era preciso, além disso, salvar Esther da perseguição de Bela Bergman, cujos passos se aproximavam do ambicionado anel, que Leizer Kochman tinha colocado no dedo de Lea, a fim de aliviá-la dos ataques epiléticos - a jovem ignorava que o anel era resultado de um furto. Lea chegou a escrever ao escritório do JCA em Paris, oferecendo sua filha como candidata à imigração para as colônias que a organização estava criando na América do Sul. Ela, entretanto, não sabia que a JCA fazia uma seleção bastante rigorosa, mostrando interesse apenas em imigrantes aptos para o trabalho agrícola, e não em jovens sem profissão alguma.

Decidida a enviar sua única filha à Argentina e, com ela, o anel, Lea viu uma oportunidade de ouro para a concretização de seu desejo quando, um dia, ela tomou ciência da chegada de um navio a Danzig proveniente de Buenos Aires. Do navio desceu e chegou à sua taverna um homem elegante, que lhe causou enorme impressão devido ao seu refinamento. Em sua boca, o espanhol era tão bem falado quanto o ídiche. Esse elegante homem, Manuel Zind, mostrou-se a pessoa certa que Lea esperava para salvar sua filha das agruras da vida na Europa. Foi através de Manuel Zind que Lea ficou sabendo que, em Buenos Aires,

os judeus se inseriam em todos os ramos do comércio da cidade e que há judeus que chegaram a acumular grande quantidade de riquezas. Em todo lugar onde há um lar judaico há também uma sinagoga riu Manuel [...] E você teve grande sorte minha senhora, eu vim até aqui para juntar jovens e levá-las para Buenos Aires. Para trabalhar em casas de judeus? Perguntou Lea. Ao que Manuel respondeu balançando silenciosamente com a cabeça. (SHEINFELD, 2007, p. 115)

Com 14 anos, Esther foi entregue por Lea Kochman aos cuidados de Manuel Zind, que, ainda, recebeu da mãe de Esther uma bela quantia em dinheiro para custear a longa viagem. Rapidamente, ela arrumou os pertences da filha e escondeu o anel num dos compartimentos 
da mala, sem que a filha soubesse. E, assim que o navio zarpou rumo a Buenos Aires, Manuel trancou Esther violentamente no porão do navio, juntamente com Miriam, a filha do rabino. Ali mesmo, ambas foram violentadas por marinheiros pagos pelo próprio Manuel.

"Os três marinheiros já sabiam que aquele homem era um rufião judeu e também conheciam que a rede de rufiões tinha uma ligação estreita com a policia de Buenos Aires. Era por essa razão que lhes permitiam descer com todas aquelas jovens dos navios sem qualquer problema. Eles sabiam e não desejavam nenhuma complicação". (SHEINFELD, 2007, p. 123)

Manuel Zind, que saiu da Europa aos 18 anos, com a intenção de enriquecer no novo mundo, tinha 30 anos e já se orgulhava de ter seu próprio bordel - com sua fiel porteira ou zeladora, Roja Rosa, uma velha prostituta que, agora, cuidava e instruía as mais jovens - e de fazer parte da rica e próspera organização Varsóvia, que, posteriormente, se transformaria na temida Zwi Migdal, a mais importante entidade dedicada ao tráfico de escravas brancas de origem judaica na América Latina. Enquanto Manuel conduzia suas vítimas para Buenos Aires, o narrador prossegue contando que Guershon e Bela Bergman receberam, na mesma época, uma proposta do Barão Hirsch, para que o ajudassem a fortalecer a atuação da JCA no amplo território das províncias argentinas - em especial, na criação de uma rede judaica de educação nas colônias agrícolas recentemente fundadas ali.

Ao desembarcar do navio, Esther e Miriam, foram conduzidas por Manuel até sua nova casa, localizada no bairro do Once, na Rua Junin, 320:

E naquela rua havia outras casas como essa. A casa de Walter e a casa de Angel, a casa de Ziskind, a de David e a de Israel. Em cada uma dessas casas havia mulheres que como elas duas, foram trazidas da mesma maneira, e de vários cantos da Europa. Em todas as casas havia homens que sabiam acariciar e bater quando necessário, que comerciavam com suas mulheres como se estas fossem animais, mas que sabiam tratar a cada uma delas, como se esta fosse uma e única. O importante era que estas mulheres arrecadassem um bom dinheiro, que não os fizessem passar por vexames, e que não ficassem grávidas. Mas para que o negócio andasse sem delongas, era necessário que as mulheres começassem a trabalhar no dia seguinte a sua chegada, sem ter tempo de se habituar, de se rebelar e muito menos, de pensar. (SHEINFELD, 2007, p. 156)

Personagens ficcionais transitam na narrativa de Sheinfeld ao lado de personagens reais. Assim, Manuel Zind reúne-se junto com outros homens na casa de Noah Trauman, um dos principais rufiões, para acertar todos os detalhes da criação da primeira agremiação de seu tipo no mundo: 
A primeira entidade que reunirá a todos os rufiões judeus da cidade, com o intuito de fornecer ajuda mútua a eles próprios e a suas mulheres [...] Precisamos criar uma organização com um caixa para ajuda mútua, com um comitê que dirima conflitos, e o mais importante, para poder estabelecer de forma ordeira a vinda de carne fresca e sua venda em leilões públicos [...] A seguir faltava decidir o nome da entidade, ao que Peretz Shtauber sugeriu a denominação "Guemilut Chassadim". (SHEINFELD, 2007, p. 189)

Quando, após um ano de sua partida rumo ao desconhecido, Esther conseguiu enviar uma carta para sua mãe, Lea, em Danzig, esta ficou horrorizada ao saber que sua filha acabara tendo o mesmo destino que ela própria: tinha sido transformada numa prostituta judia. Ela correu até a sede da comunidade judia da cidade, onde lhe foi revelado que o caso de sua filha era apenas mais um relato entre muitos outros que vinham sendo descobertos. Os membros da comunidade lhe disseram que encaminhariam seu caso até Guershom Bergman, o enviado do Barão Hirsch em Buenos Aires, a quem solicitaram "que de forma discreta, para não despertar o antissemitismo, ele verificasse o que de verdade havia nesta história e o que seria possível fazer em prol destas moças, comercializadas como escravas por judeus, aparentemente à vista de todos, dentro do bairro do Once em Buenos Aires” (SHEINFELD, 2007, p. 237).

À medida que a organização Zwi Migdal mostrava força e coesão, a comunidade judaica, que também se solidificava com sua multiplicidade de instituições e sinagogas, começou a demonstrar total oposição, e essa repulsa aos rufiões e suas mulheres era cada vez menos velada. A comunidade temia sempre ser identificada, em sua totalidade, como sendo um grupo formado por elementos negativos e abjetos perante os olhos da sociedade maior do país. O ponto de ruptura entre os chamados "puros" e os "impuros" aconteceu por ocasião do Yom Kipur, o Dia do Perdão, quando os rufiões e suas mulheres, todos eles elegantemente vestidos, se dirigiram à nova sinagoga sefaradita da Rua Camargo. Ao chegarem ali em várias carruagens, os "impuros" foram recebidos por uma multidão que bradava: "Fora, rufiões!". Ao tentarem argumentar que todos eles faziam parte de um mesmo povo, aconteceu que

repentinamente do meio do público apareceu um homem alto e de barba. Na cabeça ele usava uma cartola preta e vestia um elegante paletó. Sua imagem era a de um rico industrial ou um pensador ou intelectual renomado. "Não há lugar para vocês aqui", anunciou o rabino Halperin, "Não há lugar para vocês aqui neste lugar puro e sagrado". Ao que a multidão somou-se gritando: "Fora, rufiões". (SHEINFELD, 2007, p. 266)

\footnotetext{
${ }^{6}$ Guemilut Chassadim - Literalmente, "caridade", "benevolência", "filantropia", segundo BEREZIN, Rifka. Dicionário Hebraico-Português. São Paulo: EDUSP, 2003.
} 
A expulsão em Yom Kipur e o vexame por eles sofrido incentivaram os "impuros" a criarem sua própria rede de instituições comunitárias. Um tempo depois, eles adquiriram um prédio com dois andares na Av. Córdoba, em pleno centro da cidade de Buenos Aires. No andar térreo, ergueram a sinagoga, a $m i k v a^{7}$ e um salão de encontros e de celebrações. Com seu poderio econômico, contrataram seu próprio rabino, além do cantor litúrgico e do zelador para a sinagoga. O prédio era vigiado por policiais pagos pela Zwi Migdal, e, apesar de terem escandalizado a comunidade judaica, em todo o período em que a sinagoga dos rufiões existiu, foram celebradas nela as rezas das grandes festas, shabatot, cerimônias de circuncisão, casamentos e até as comemorações de Bar Mitzvá, a maioridade religiosa para os meninos membros daquela organização.

No Yom Kipur de 1895, Lea Kochman, que tinha se desfeito do anel capaz de aliviá-la da epilepsia e o tinha enviado no navio rumo a Buenos Aires em que embarcara a sua filha, morreu. Após o falecimento da mãe em Danzig, estando sozinha no mundo, Esther assumiu o anel que, até então, guardava em seu quarto e transformou-se numa das mais renomadas prostitutas da cidade, por sua elegância e refinamento. Na outra família da narrativa de Sheinfeld, Bela Bergman, já em Buenos Aires, para onde se mudara com seu marido, alto funcionário do Barão Hirsch no país, continuava obcecada por recuperar o famoso anel. Ela foi atingida pela doença de lúpus, que começou a danificar sua pele, e seus dois filhos herdaram da avó materna, Raine Haia, a epilepsia, doença que se intensificava a cada dia. O ódio de Bela Bergman por Esther e, por conseguinte, pela Zwi Migdal, organização que maculava toda a comunidade judaica da Argentina, intensificou-se ao longo de toda a narrativa em solo argentino.

Esther ficou grávida, e, em 1912, contrariando as ordens de Manuel Zind, nasceu Esperanza Lea, a terceira geração da família Kochman. Manuel, "dono" da vida de Esther, ficou irado e ordenou que a criança recém-nascida fosse entregue a um orfanato, tal qual tinha acontecido com a própria Esther, a qual, sendo uma bastarda, também teve que passar a infância confinada num orfanato, junto com o anel, que servia como garantia da permanência dela na instituição. Por outro lado, Bela Bergman, no final de sua vida e sem ter conseguido recuperar o desejado anel, se dirigiu até o inspetor Julio Alsogaray, como membro atuante da organização feminina Ezrat Nashim, decidida a ajudar a desmontar a Zwi Migdal.

\footnotetext{
${ }^{7}$ Mikvá - compartimento para o banho ritual e de purificação, tanto para mulheres como para homens.
} 
Novamente, na narrativa, personagens ficcionais atuam ao lado de personagens reais. Bela Bergman assume o papel real exercido por Raquel Liberman, a prostituta que ajudou, na vida real, em 1930, a desmontar a organização criminosa, juntamente com o inspetor de polícia. $\mathrm{Na}$ narrativa de Sheinfeld, o inspetor da policia argentina invadiu a casa de Manuel Zind para prendê-lo e libertar de lá as jovens que se achavam sob seu manto opressivo. Revirando os quartos, Alsogaray encontrou inúmeros documentos que poderiam incriminar a organização entre eles, o caderno de donativos que eram entregues pelos diferentes associados para a manutenção econômica da Zwi Migdal. Alsogaray também tinha por objetivo encontrar o anel de Bela Bergaman, em posse do qual, no entanto, estava Esther Kochman, que, aproveitandose da confusão reinante no lugar após a invasão da polícia, fugiu da casa em que se achava para a liberdade.

Em 1930, com a agitação social e econômica, ocorreu também, em Buenos Aires, um levante militar. O clima de anarquia espalhou-se pelo país. A casa de Manuel Zind e outras casas de rufiões judeus foram incendiadas. Roja Rosa, Miriam, a filha do rabino, e outras mulheres morreram no incêndio. Somente Esther sabia quem tinha causado aquele espetáculo de ódio, vingança e fogo.

\begin{abstract}
Após o incêndio cessar, os policiais entraram nas casas a procura de provas, documentos e testemunhas. Entre as testemunhas havia aqueles que culpavam os anarquistas pelo incêndio. Mas outros disseram que os verdadeiros culpados eram os estudantes de direito que após se divertirem com as prostitutas francesas, resolveram queimar as prostitutas judias. Os proprietários das casas, no entanto, concordaram entre si, que os verdadeiros culpados deveriam ser procurados dentro das sinagogas, e que o responsável era certamente um judeu, desejoso de limpar o mundo da mácula. Não é a toa que nos chamam de impuros, assim disseram. Somente minha mãe sabia (diz Esperanza Lea) então da verdade: Bela Bergman aproveitou-se do estado de anarquia e agitação que reinava na cidade e enviou a seu cocheiro, Santo, para que este incendiasse com o fogo de seu desejo de vingança, aquela casa e as mulheres impuras que nela se encontravam. (SHEINFELD, 2007, p. 352 - 353)
\end{abstract}

Libertada das mãos de Manuel Zind, mas não livre do estigma que era imposto a ela e a todas as que, como ela, haviam seguido a mesma trilha, Esther abriu seu próprio negócio, no mesmo ramo, e, nesse ínterim, casou-se com um velho comerciante de tecidos chamado Itzchak Gants, o qual lhe deu proteção e lhe outorgou seu sobrenome, a fim de tentar livrá-la do passado. Esther Kochman morreu em 1930, deixando sozinha a sua filha, Esperanza Lea Gants, que tinha 18 anos. Esther foi sepultada discretamente no cemitério de La Tablada, 
numa área separada e reservada para mulheres que, como ela, tinham a mesma marca do opróbio e da vergonha.

Em 6 de setembro de 1930, o presidente argentino, Bernardo de Irigoyen, foi deposto por uma junta militar liderada pelo general José Felix Uriburo. Esse golpe foi também a etapa final da organização Zwi Migdal. É aqui que Raquel Liberman entra na narrativa de Sheinfeld para pôr um fim à entidade criminosa. A denúncia de Liberman fez com que alguns membros da organização fugissem para Montevidéu, no Uruguai, e outros para o Sul do Brasil.

A narradora do romance é Esperanza Lea Gants, que revela para a sua filha Flor a mácula que pairou sobre sua família por três gerações, já que a própria Esperanza passou a dedicar-se à prostituição a partir de seus 18 anos. Assim narra Esperanza à sua filha, revelando todo o seu passado:

"Eu nasci na Argentina, mas eu nasci impura, sou filha de impuros e assim o serei até envelhecer e morrer. Não escolhi este destino. É verdade que eu poderia ter fugido para um país distante e ali começar uma nova vida. Mas para isso eu deveria ter renunciado a tudo, a este país, a sua língua, às memórias que nunca foram as minhas". (SHEINFELD, 2007, p. 398)

É com essas palavras que Esperanza Lea decide revelar seu passado à sua filha Flora. Muitas das mulheres marcadas pela vergonha mudaram-se para as pequenas cidades do interior argentino e ali abriram pensões ou pequenos bordéis próprios.

No final do romance, a família Bergman se une, de certa forma, à família Kochman, quando José Bergman, filho de Guershon e Bela, oferece proteção a Esperanza Lea Gants e sua filha Flora, e o anel, então, passa a ser compartilhado pelas duas famílias. Com esse ato, o anel vai redimir Esperanza e sua filha da mácula do passado. A junta militar derrubou o governo democrático na Argentina em março de 1976. A comunidade judaica foi abalada fortemente, e centenas ou milhares de seus membros foram presos sob a acusação de serem subversivos. Esperanza Lea e Flora, judias, uma militante de esquerda, a outra uma antiga prostituta, passíveis de serem duplamente acusadas como indesejáveis, atravessaram o Rio da Prata e chegaram a Montevidéu. Mas, como a ameaça era real em vários países da América Latina dominados por ditaduras militares, as duas decidiram imigrar para Israel, lugar onde toda a saga é desvelada perante Flora Gants - uma história terrível mantida por décadas no ostracismo. Mas é em Israel, décadas depois e já no final de sua vida, que Esperanza decide 
contar à sua filha seu passado - passado nebuloso, que, até os nossos dias, ainda provoca espanto e rejeição, vergonha e distanciamento.

Se é verdade que as moças transformadas em prostitutas à força e seus rufiões faziam questão de manter seus laços com sua religião e tradição e não se assimilavam à sociedade maior, também fica claro que era impossível não absorver elementos da cultura local argentina. No romance de Sheinfeld, Miriam, a filha do rabino, que foi levada para a Argentina no mesmo navio que Esther, encontrou a velha caixa de jóias de Esther, que estava escondida em seu quarto, e, dentro da caixa, ela achou o velho anel com poderes místicos. Esther contou a Miriam as andanças do anel desde Danzig até Buenos Aires, e, nesse momento, Miriam saiu entoando uma canção que, segundo o romance, tornou-se uma das preferidas da cidade de Buenos Aires. Ao som de um tango, ritmo musical que se originou justamente nos bordéis da cidade, a canção evoca a saga de centenas de mulheres que, arrancadas de seus lares, foram lançadas numa vida de vergonha e opressão. Ainda hoje, pairam sobre elas e seus descendentes o esquecimento e o silêncio. Estas são as palavras da canção da opressão, entoadas por Miriam, no bordel de Manuel Zind, em Buenos Aires, como a única manifestação possível de protesto:

Se quiserem chorar então ouçam

A história de Nina, a filha do rabino,

Um dia chegou um estranho que a cobriu com uma pedra,

Que em torno da mesma, havia um aro de ouro.

E ela foi atrás dele com seu coração e sua alma,

Pois ela era jovem e ingênua,

E ele a puxou para dentro da lama

$\mathrm{E}$ a colocou à venda sem piedade.

Nina, Nina, para onde você foi, sendo ainda uma menina,

Você que não sabia o que era um homem

Numa diaba transformou-se.

Dia após dia ela ali trabalhava de forma árdua,

Até se transformar numa mulher famosa,

Cada um a conhecia na cidade,

Chamando-a de Nina, a vermelha Nina.

Até que um dia por causa daquele anel,

Seu coração se encheu de ira e amargura.

Com uma lâmina a cabeça do anel ela arrancou,

E a escondeu embaixo de um travesseiro.

Nina, Nina, para onde você foi, sendo ainda uma menina, Você que não sabia o que era um homem 
Numa diaba transformou-se.

Eles a levaram para a prisão,

E sobre suas mãos lhe puseram algemas,

E ela arrancou seus próprios olhos

Que se transformaram em duas cavidades vazias.

E desde então brilha aquele anel

Frente a uma velha prostituta, a filha do rabino.

E no meio da escuridão novamente surge

$\mathrm{O}$ rosto do homem que verdadeiramente, um dia a amou.

Nina, Nina, o que você fez, mulher diaba,

Dentro dos teus olhos você está deitada,

Como dentro de um túmulo, solitária. (SHEINFELD, 2007, p. 258-259) 


\section{Bibliografia}

ALSOGARAY, J. Trilogia da la trata de Blancas. Buenos Aires: Editorial Tor: 1933.

ARAZI, E. Beit hakvarot shel hazonot hayehudiot [O cemitério das prostitutas judias]. Haaretz, 16/04/2015. Disponível em <http//www.haartez.co.il/magazine/premium1.2614772> Acesso em: 11 mai. 2016.

CHERVONAGURA, E. C. La prostitución judia y su discurso a la luz de un expediente judicial. Revista de Estudios Culturales de la Universitat Jaume I. Vol. IX, p. 31 - 51, 2011

DILLON, M. Romper el silencio. Página 12, 26/09/2003. Disponível em

$<\mathrm{http} /$ www.pagina12.com.ar/diário/suplementos/las12/12-797-2003-09-28.html> Acesso em: 11 mai. 2016.

DRUCAROFF, E. El infierno prometido: Una prostituta de la Zwi Migdal. Buenos Aires: Sudamericana, 2006.

FEIERSTEIN, R. História de los judios argentinos. Buenos Aires: Galerna, 2006.

HERMONI, M. Ma, zonot yehudiot lo neenot misex brutali tov? [O que? Prostitutas judias não gostam de um bom sexo brutal?]. Haaretz, 04/06/2007. Disponível em $<$ http//www.haaretz.co.il/misc/article-print-page/1.1415392> Acesso em: 11 mai. 2016.

KUSHNIR, B. Baile de máscaras. Rio de Janeiro, Imago, 1996.

LORI, A. Rachel Lea Liberman haytá haprutzá hayehudiá sheepila het hamafia hayehudit beArgentina [Raquel Lea Liberman foi a prostituta judia que derrubou a máfia judia em Buenos Aires]. Haaretz, 01/05/2009. Disponível em $<$ http//www.haaretz.co.il/misc/article-print-page/1.1258486> Acesso em: 11 mai. 2016.

MARTIELlO, L. M. Apuntes para una história de la prostitución en Buenos Aires. Disponível em: <http//revistapersona.com.ar/persona37/37martiello.htm> Acesso em: 25 abr. 2016.

SCHALOM, M. La Polaca. Buenos Aires: Galerna, 2013.

. Raquel Liberman: una polaca judia en el Buenos Aires del 30. Temas de Patrimonio Cultural 19 - Buenos Aires Ídish. Buenos Aires: Gobierno de la Ciudad de Buenos Aires, 2006.

SCLIAR, M. O Ciclo das águas. Porto Alegre: Editora Globo, 1982.

SHEINFELD, I. Maassê Betabaat. Jerusalém: Keter, 2007. 